\title{
An Analysis of Trade Patterns in East Asia and the Effects of the Real Exchange Rate Movements
}

\author{
Moon Jung Choi* ${ }^{*}$ Geun-Young Kim**, Joo Yong Lee***
}

The views expressed herein are those of the authors and do not necessarily reflect the official views of the Bank of Korea. When reporting or citing this paper, the authors' names should always be explicitly stated.

\footnotetext{
* Economic Research Institute, The Bank of Korea, E-mail: mjchoi@bok.or.kr.

** Economic Research Institute, The Bank of Korea, E-mail: kgy3104@bok.or.kr.

*** Corresponding author. Economic Research Institute, The Bank of Korea, E-mail: 1jy@bok.or.kr.

The authors are grateful to Woon Gyu Choi, Hyun-Jeong Kim, Kyungmin Kim, Tae Jeong Kim, Dongyeol Lee, Jin-Su Park, Seryoung Park, and participants in the seminar at the Bank of Korea for their helpful comments.
} 


\section{Contents}

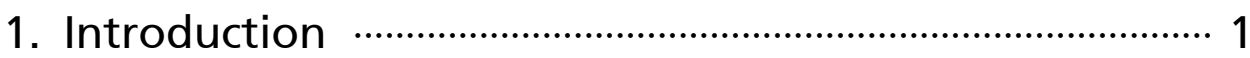

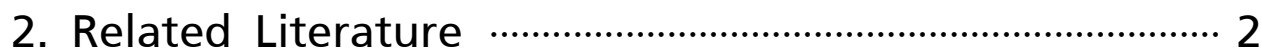

3. Theoretical Model ……........................................................... 4

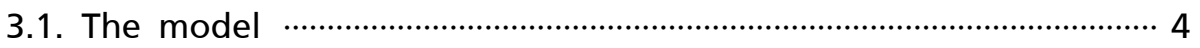

3.2. Trade in the multistage production ……....................................... 9

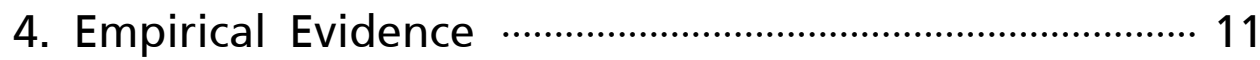

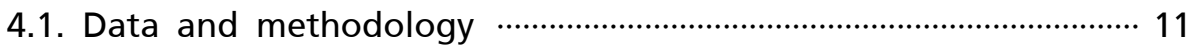

4.2. Identification

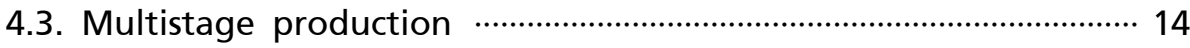

4.4. Effects of real exchange rate movements ….............................. 17

5. Concluding Remarks ………………………………....... 23

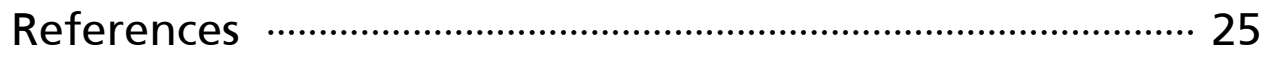

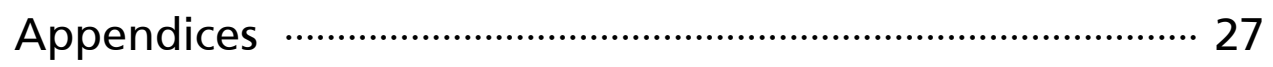




\section{An Analysis of Trade Patterns in East Asia and the Effects of the Real Exchange Rate Movements}

This paper investigates how patterns of vertical specialization in trade among the three major East Asian economies - China, Japan and Korea-are shaped, and what the effects of the real exchange rate fluctuations on trade volumes are. We develop a simple two-country model that focuses on the multistage production process, and apply Time-Varying Parameter (TVP) VAR to the countries' bilateral trade data. From our theoretical model, we find two distinct features of vertical specialization where multistage production processes occur: one is that, when a multistage production process exists, an increase in final demand in one country causes both countries' intermediate goods exports to expand; the other is that, if a multistage production process exists in the production of one country's final goods, then real depreciation of the currency in the other country has an amplified effect through the circulating trade chain. In the following empirical analysis, we first find that a multistage production process is prominent in the production of China's final consumption goods. Another finding is that the existence of a multistage production process across two countries, especially Korea and China, strengthens the effect of the real exchange rate on intermediate goods trades through the amplified effect that the theoretical model predicts.

Keywords: Vertical specialization, Multistage production, Real exchange rate, Time varying parameter VAR

JEL classification: C32, F12, F14, F15 


\section{Introduction}

Global trade has grown rapidly for decades, in terms both of volume and of interconnectedness. Recent research on vertical specialization across countries reveals that the volume of trade and the degree of interconnectedness are not totally separate. International vertical specialization not only changes global trade patterns, but because of the role of intermediate goods also complicates the effects on trade volume due to real exchange rate movements. As Greenaway et al. (2010) point out, real appreciation makes domestic firms' exports more expensive, while at the same time making imported intermediate goods cheaper.

Recent studies on East Asia report that vertical specialization in this area has grown rapidly and enormously. Both the share of parts and components (e.g., Athukorala, 2005) and indices of vertical intra-industry trade (e.g., Wakasugi, 2007) demonstrate an increasing pattern of vertical specialization. Unlike the prevalent research on vertical specialization in East Asia, we focus here on the three major countries in East Asia, i.e. the Korea-China pair and the Korea-Japan pair, because China, Japan, and Korea are more intertwined in their production processes than other countries in addition to their geographical and historical closeness.

Considering that there is rich evidence of increasing vertical specialization, we investigate the deepening of vertical specialization across countries by focusing on the multistage production process. As the number of production stages increases, two countries become more interdependent in producing their intermediate goods. Compared to one-way trade of intermediate goods (i.e. a one-stage production process), multistage production makes the transmission mechanism of real exchange rate fluctuations more complicated.

By extending the multistage production model of Yi (2010), we derive two characteristics of a multistage production process across countries. The first is that, when a multistage production process is well developed, changes in various components of final demand force foreign and home intermediate exports to move in the same direction. Intuitively, stronger connectedness among intermediate goods production firms causes both home and foreign intermediate 
goods exports to increase in response to a positive demand shock. The second characteristic we find is that terms of trade fluctuations have amplified effects on home and foreign intermediate goods exports through the vertical specialization chain. This is also intuitive. Compared to the case with one-way intermediate goods imports, imported intermediate good inputs are used as parts of other inputs in line with the vertical specialization chain. Hence the influence of the terms of trade becomes larger through the chain.

From the empirical work on vertical specialization, we first find that a multistage production process is prominent in the production of China's final consumption goods. Unlike in the Korea-China country pair, we do not find any significant multistage production process in the Korea-Japan country pair. Another interesting finding is that the existence of a multistage production process between two countries, especially in the Korea-China pair, strengthens the effect of the real exchange rate on intermediate goods trade through the amplified effect that our theoretical model predicts.

This paper proceeds as follows. Section 2 discusses the related literature. Section 3 then describes the theoretical model. Section 4 presents the estimation results, and Section 5 contains our concluding remarks.

\section{Related Literature}

By adopting and modifying the models of Yi (2003) and Yi (2010), we construct a theoretical model for analyzing trade patterns and the effects of the real exchange rate fluctuations. We introduce a demand shock to the model to examine the behaviors, with respect to changes in final demand, of intermediate goods exports in both the home and the foreign countries. We replace the tariffs in Yi (2010) with (real) terms of trade fluctuations to explore the amplified effect of the terms of trade.

In empirical work on trade patterns in Korea-China or Korea-Japan, we are in line with the Input-Output (I-O) table approach as in Hummels et al. (2001) and Suh (2008). For analyzing vertical trade, delving into one-way trade in parts and 
components (Athukorala and Yamashita, 2006) or the index of intra-industry trade (Kimura et al., 2007) had been the prevalent ways.1) But in the context of the definition of vertical specialization in Hummels et al. (2001), neither approach is sufficient for capturing the essence of vertical specialization.2) Following Hummels et al. (2001), Suh (2008) develops two measures of vertical trade - bilateral Vertical Export (VE) and Vertical Import (VI) indices. ${ }^{3)}$ In this paper we do not utilize the I-O table as in Hummels et al. (2001) or Suh (2008) but instead directly estimate the induced intermediate goods demand, the concept that I-O table analysis connotes.

This paper is related to the research area where the effects of real exchange rate fluctuations are investigated, but the focus and methodology differ somewhat. Estimation of the long-run export-demand relationship, as in Thorbecke (2008),4) is typical in analysis of the effects of real exchange rate movements.5) Including exchange rate volatility in the long-run export-demand relationship is one recent development in this direction. To name a few, this is done by Baak et al. (2007), Chou (2000), Chowdhury (1993), Arize (1995) and Arize et al. (2000).6) Our work deviates from this line of research in two ways. One is that we are interested in the short- or medium-term effects of the real exchange rate movements. For this purpose we adopt a Time-Varying Parameter (TVP) VAR approach following Primiceri (2005) and Canova and Forero (2012). The other difference in our approach is that, by applying time-varying stochastic volatility from Kim et al. (1998) and Canova and Forero (2012), we control the volatility of the real exchange rate directly inside the model.

1) For a summary of those studies on East Asia, see Suh (2008).

2) The existence of a multistage production process across countries causes this insufficiency.

3) The indices of Suh (2008) differ from those of Hummels et al. (2001) in that Suh's (2008) indices are bilateral.

4) Thorbecke (2008) applied the panel DOLS method to avoid the reverse causality problem.

5) There is also the estimation of a gravity equation model. For more about that model, see Rose (2000) and Berthou (2008).

6) Baak et al. (2007), Chou (2000), Chowdhury (1993), Arize (1995) and Arize et al. (2000) use the Error Correction Model (ECM). By using DOLS, Arize et al. (2000) show the robustness of the cointegration results. For exchange rate volatility, Chowdhury (1993), Baak et al. (2007), and Arize et al. (2000) utilize standard deviations; Chou (2000) and Arize (1995) meanwhile adopt ARCH(1). 


\section{Theoretical Model}

We construct a model based on the model of Yi (2010). We introduce a preference shock to households and a (real) terms of trade shock. By adding a preference shock to the model we specify the effect of an increase in demand on intermediate goods exports, which reflects an essential feature that arises when a multistage production process exists. We replace the tariffs in Yi (2010) with the (real) terms of trade and investigate the amplified effect of the (real) terms of trade.

\subsection{The model}

We develop a Ricardian two-country model. There are the home and the foreign countries. Each country produces a continuum of goods, $z \in[0,1]$. There are two stages in the production of either final consumption goods or intermediate goods. In the sense that aggregate intermediate goods are reallocated to the stage 1 production, the model here represents multistage production.

\subsubsection{Technologies}

The production function of stage 1 good in the home country is given by

$$
y_{1}^{H}(z)=A_{1}^{H}(z) \ell_{1}^{H}(z)^{1-\theta_{1}} M^{H}(z)^{\theta_{1}}, \quad z \in[0,1],
$$

where $y_{1}^{H}(z)$ represents stage $1 \operatorname{good} z$ in the home country. $A_{1}^{H}(z)$ denotes total factor productivity of stage $1 \operatorname{good} z$ in the home country. $\ell_{1}^{H}(z)$ is labor input for stage $1 \operatorname{good} z$ in the home country. $M^{H}(z)$ denotes aggregate intermediate good $M^{H}$ that is used in the production of stage $1 \operatorname{good}$ in the home country. $\theta_{1}$ is the share of aggregate intermediate good. Stage 1 goods are assumed to be tradable. The same production function applies to the foreign country. 
The production function of stage 2 good in the home country is

$$
y_{2}^{H}(z)=A_{2}^{H}(z) \ell_{2}^{H}(z)^{1-\theta_{2}} x_{1}^{H}(z)^{\theta_{2}}, \quad z \in[0,1]
$$

where $y_{2}^{H}(z)$ represents stage $2 \operatorname{good} z$ in the home country. $A_{2}^{H}(z)$ is total factor productivity of stage $2 \operatorname{good} z$ in the home country. $\ell_{2}^{H}(z)$ denotes labor input for stage $2 \operatorname{good} z$ in the home country. $x_{1}^{H}(z)$ represents stage $1 \operatorname{good} z$ that is used in the production of stage 2 good in the home country. $\theta_{2}$ is the share of stage 1 good. Stage 2 goods are also tradable. Stage 2 goods are either directly consumed or used as input for aggregate intermediate good, $M^{H}$. The foreign country is assumed to have the same production function.

Stage 2 goods are aggregated into an intermediate good as

$$
M^{H}=\left[\left(\int_{0}^{1} m^{H}(z)^{\frac{\sigma-1}{\sigma}} d z\right)^{\frac{\sigma}{\sigma-1}}\right],
$$

where $m^{H}(z)$ is stage 2 good $z$ in the home country.

We introduce a (real) terms of trade shock instead of the iceberg type tariffs in Yi (2010).7) The terms of trade shock is given by $t o t^{F H}$, which is the unit price of foreign currency in terms of home currency. Note that $\operatorname{tot}^{F H}=1 / \operatorname{tot}^{H F}$.

\subsubsection{Prices}

We assume that prices are determined under perfect competition in all stages of production.

The price of stage 1 good $z$ in the foreign country that are demanded by the stage 2 firm in home country is

7) Considering smaller geographical distance both in the Korea-China and the Korea-Japan country pairs, we omit all other distribution costs. 


$$
p_{1}^{F H}(z)=\frac{t o t^{F H} \psi\left(W^{F}\right)^{1-\theta_{1}}\left(P^{F}\right)^{\theta_{1}}}{A_{1}^{F}(z)},
$$

where $\psi=\left(1-\theta_{1}\right)^{-\left(1-\theta_{1}\right)} \theta_{1}^{-\theta_{1}}$. $\quad W^{F}$ denotes the nominal wage in the foreign country and $P^{F}$ represents the price of aggregate intermediate good in the foreign country. The stage 2 firm in the home country actually pays for the price of stage 1 good,

$$
p_{1}^{H}(z)=\min \left[p_{1}^{F H}(z), p_{1}^{H H}(z)\right],
$$

where $p_{1}^{H H}(z)$ is the price of stage 1 good in the home country paid by the stage 2 firm in the home country.

The price of stage 2 good $z$ in the home country that are demanded by a consumer or a firm in the foreign country is

$$
p_{2}^{H F}(z)=\frac{t o t^{H F} \psi\left(W^{H}\right)^{1-\theta_{2}}\left(P^{H}\right)^{\theta_{2}}}{A_{2}^{H}(z)},
$$

where $W^{H}$ is the nominal wage in the home country and $P^{H}$ is the price of aggregate intermediate good in the home country. The consumer or aggregate intermediate goods producing firm in foreign country actually pays for the price of stage 2 good in the home country,

$$
p_{2}^{F}(z)=\min \left[p_{2}^{H F}(z), p_{2}^{F F}(z)\right]
$$

where $p_{2}^{F F}(z)$ is the price of stage 2 good in the foreign country paid by a foreign consumer or a foreign intermediate good producing firm. 


\subsubsection{International vertical specialization}

Following Hummels et al. $(2001)^{8)}$ and $\mathrm{Yi}$ (2010), we assume that international vertical specialization between two countries occur when a country producing and exporting stage 1 good is the same country that demands final consumption goods. For example, vertical specialization takes place in the following way: Country A produces and exports stage 1 good; country B imports this stage 1 good and exports stage 2 good to country A; using imported stage 2 good, country A produces final consumption goods.

\subsubsection{Household's problem}

The representative household in the home country maximizes the utility

$$
\xi \ln C^{H}-\phi \frac{1}{1+\frac{1}{\chi}}\left(L^{H}\right)^{1+\frac{1}{\chi}}
$$

where $C^{H}$ and $L^{H}$ represent aggregate consumption bundle and aggregate labor supply respectively. $\xi$ denotes a preference shock or a demand shock. $\chi$ is the wage elasticity of Frisch labor supply and $\phi$ is a constant. Aggregate consumption bundle $C^{H}$ is given by

$$
C^{H}=\left[\left(\int_{0}^{1} c^{H}(z)^{\frac{\sigma-1}{\sigma}} d z\right)^{\frac{\sigma}{\sigma-1}}\right]
$$

where $c^{H}(z)$ is consumption of stage 2 good in the home country. Corresponding household budget constraint is

8) Hummels et al. (2001) define that vertical specialization occurs when i) a good is produced in two or more sequential stages, ii) two or more countries provide value-added during the production of the good, and iii) at least one country must use imported inputs in its stage of the production process, and some of the resulting output must be exported. 


$$
\int_{0}^{1} p^{H}(z) c^{H}(z) d z=W^{H} L^{H}
$$

where $p^{H}(z)$ denotes the price of stage $2 \operatorname{good} z$. In case stage $2 \operatorname{good} z$ is produced in the foreign country, $p^{H}(z)=p_{2}^{F}(z) \cdot t o t^{F H}$. One can further construct aggregate price index for consumption goods as $P^{H}$.

\subsubsection{Equilibrium}

We assume perfect competition in all factor and goods markets. Market clearing conditions are given by

$$
\begin{gathered}
L^{i}=\int_{0}^{1} \ell_{1}^{i}(z) d z+\int_{0}^{1} \ell_{2}^{i}(z) d z, \quad i=H, F, \\
y_{1}(z)=y_{1}^{H}(z)+y_{1}^{F}(z)=\operatorname{tot}^{H} x_{1}^{H}(z)+\operatorname{tot}^{F} x_{1}^{F}(z), \\
y_{2}(z)=y_{2}^{H}(z)+y_{2}^{F}(z)=\operatorname{tot}^{H}\left[c^{H}(z)+m^{H}(z)\right]+\operatorname{tot}^{F}\left[c^{F}(z)+m^{F}(z)\right], \\
M^{i}=\int_{0}^{1} M^{i}(z) d z, \quad i=H, F,
\end{gathered}
$$

where $t o t^{H}$ and $t o t^{F}$ represent (real) terms of trade shocks that occur when shipping stage 1 (or 2) good from the cheapest production country to the home and the foreign country respectively. As in Yi (2003) and Yi (2010), these conditions imply balanced trade. We define the equilibrium as below.

Definition 1. An equilibrium is a sequence of goods and factor prices, $\left\{p_{1}^{i}(z), p_{2}^{i}(z)\right.$, $\left.P^{i}, w^{i}\right\}$ and quantities, $\left\{\ell_{1}^{i}(z), \ell_{2}^{i}(z), y_{1}^{i}(z), y_{2}^{i}(z), x_{1}^{i}(z), c^{i}(z), m^{i}(z), M^{i}(z), M^{i}\right\}$, $z \in[0,1], i=H, F$, such that households maximize utility (8), firms maximize profit related to (1), (2) and (3), and all goods and factor markets clear. 


\section{Figure 1: Production Process in the Foreign Country}

\section{Case 1}

$$
\text { Stage } 1
$$

Stage 2 Final Goods

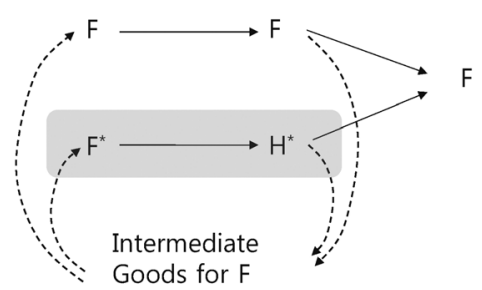

$\mathrm{H}^{*}$ : home exports to the foreign country $\mathrm{F}^{*}$ : foreign exports to the home country Shaded area: international vertical specialization.

\section{Case 2}

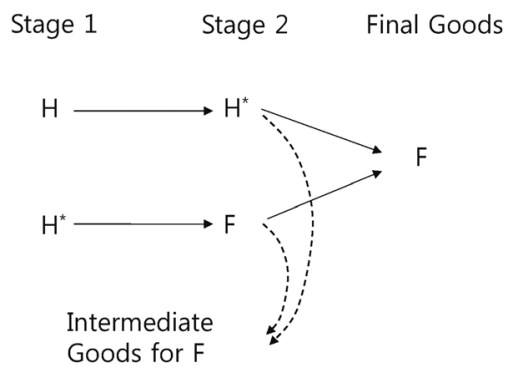

\subsection{Trade in the multistage production}

In this section we derive distinct features that arise when a multistage production process exists across two countries. For this purpose we focus on the special cases instead of dealing with all possible cases. There are possible two types of foreign final good production as in Figure 1. Because Case 1 in Figure 1 describes multistage production process, we only focus on Case 1.9)

We arrange goods in descending order of the ratio of home productivity to foreign productivity as in Dornbusch et al. (1977) and Yi (2010). Hence $A(z)=A^{H}(z) / A^{F}(z)$ is diminishing with respect to $z$. The home country produces goods on the interval $[0, \underline{z}]$, the foreign country, $[\underline{z}, 1]$.

When a multistage production process exists in the production of foreign final goods, home and foreign exports of intermediate goods for the production of foreign final goods are

9) Yi (2010) discusses that margins from Case 2 will be only a fraction of goods and the overall effect will be smaller compared to Case 1 . 
Figure 2: Production Process in the Home Country

Case 3

Stage 1

Stage 2

Final Goods

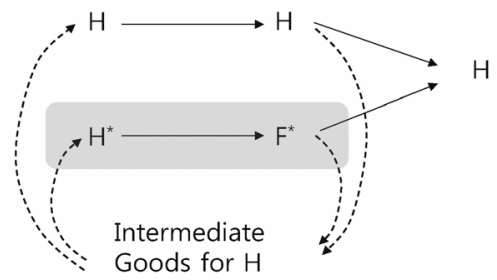

$\mathrm{H}^{*}$ : home exports to the foreign country

$\mathrm{F}^{*}$ : foreign exports to the home country

Shaded area: international vertical specialization.

\section{Case 4}

Stage $1 \quad$ Stage $2 \quad$ Final Goods

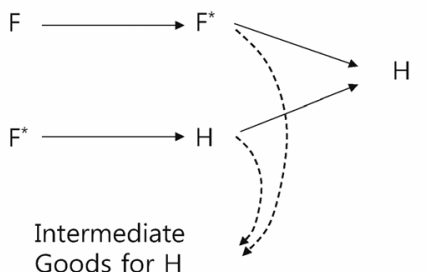

$$
\begin{aligned}
& H^{*}=\frac{\underline{z}\left(1+\theta_{2}\right)\left(W^{F} / P^{F}\right) L^{F}}{1-\theta_{1} \theta_{2}}, \\
& F^{*}=\theta_{1} \frac{\underline{z}\left(1+\theta_{2}\right)\left(W^{F} / P^{F}\right) L^{F}}{1-\theta_{1} \theta_{2}} .
\end{aligned}
$$

Note that input-output structures of foreign and home countries blow up final demand by the factor of $\left.\left(1+\theta_{2}\right) /\left(1-\theta_{1} \theta_{2}\right) .10\right)$ Assuming a functional form for the relative productivity as in $\mathrm{Yi}(2010),{ }^{11)}$ we derive the solution for the breakpoint $\underline{z},{ }^{12)}$

$$
\underline{z}=\frac{\left(\operatorname{tot}^{H F}\right)^{n}}{1+\left(\operatorname{tot}^{H F}\right)^{n}} .
$$

From the equations (15)-(17), we specify two properties that come from the multistage production process across countries. ${ }^{13)}$ First, when there is a

10) We assume $\sigma=1$ for simplicity to abstract internal margin in Yi (2003).

11) Yi (2010) assumes a Frech'et distribution for A(z).

12) For a detailed derivation, refer to Appendices A.2.

13) The same reasoning applies to home final demand as in Case 3 in Figure 2. 
positive preference shock in the foreign country, foreign and home exports of intermediate goods both increase. A positive preference shock leads to labor supply increase, hence an increase in foreign final demand follows. ${ }^{14)}$ When foreign final demand increases, both home and foreign exports of intermediate goods increase as in (15) and (16).15) Second, an improvement in the real terms of trade, i.e. real depreciation, has an amplified effect on both home and foreign exports of intermediate goods. The break point $\underline{z}$ in the multistage model is same as that in the one-stage model.16) In spite of the same $\underline{z}$, however, the effect on home and foreign intermediate good exports is amplified through input-output structure.17)

\section{Empirical Evidence}

Based on the theoretical predictions, we apply the Time-Varying Parameter (TVP) VAR method to estimate the effects of an increase in final demand on intermediate goods exports of Korea and China (or Japan), as well as the effects of the real exchange rate on final and intermediate goods trades.

\subsection{Data and methodology}

We construct a 5-variable VAR for estimating the effects of an increase in final demand on intermediate goods exports and a 4-variable VAR for estimating the effects of real exchange rate fluctuations.

The five variables in the Korea-China country pair are the CP rate (91 days), the (won-yuan) real exchange rate, China's exports to the US and the Euro

14) Real wage can either rise or fall depending on the relative position of labor supply and demand curves.

15) If a multistage production process does not exist, foreign exports to home country do not increase in response to an increase in foreign demand.

16) For a detailed derivation, refer to Appendices A.

17) The result of this paper is different from that of Yi (2010). Compared to the effect of tariffs in Yi (2010), the degree of amplification is lower. In Yi (2010), tariffs have an amplified effect on $\underline{z}$ in addition. This is because, unlike tariffs, real depreciation in one country implies real appreciation in other countries. 
area,18) Korea's intermediate goods exports to China, and China's intermediate goods exports to Korea. In the Korea-Japan country pair the five variables are the CP rate (91 days), the (won-yen) real exchange rate, Japan's exports to US and Euro area,19) Korea's intermediate goods exports to Japan, and Japan's intermediate goods exports to Korea. All variables excepting the CP rate are HP-filtered.

In the 4-variable VAR for the Korea-China country pair the variables are the (won-yuan) real exchange rate, China's exports to the US and the Euro area, Korea's final goods exports to China, and Korea's intermediate goods exports to China, and for the Korea-Japan country pair, they are the (won-yen) real exchange rate, Japan's exports to the US and the Euro area, Korea's final goods exports to Japan, and Korea's intermediate goods exports to Japan. All variables are HP-filtered.

We draw the CP rate, CPIs and the nominal exchange rate data from the Bank of Korea, and the (nominal) export data from the Korea International Trade Association (KITA). All data are monthly, and span from 1998M1 to 2015M2. The real exchange rate data are calculated from the nominal exchange rate and the CPIs. Harmonized System (HS) 6-digit product-level export data from the KITA are rearranged into the BEC classification of three stages, i.e. primary goods, ${ }^{20)}$ intermediate goods, and final goods. Export data are converted into real terms by applying the export-import price indices of Korea.21)

Our TVP VAR model is given by

$$
\begin{gathered}
\mathrm{y}_{t}=\mathrm{B}_{0, t} \mathrm{D}_{t}+\mathrm{B}_{1, t} \mathrm{y}_{t}-1+\cdots+\mathrm{B}_{p, t} \mathrm{y}_{t-p}+\mathrm{u}_{t}, \\
\mathrm{u}_{t}=\mathrm{A}_{t}^{-1} \sum_{t} \varepsilon_{t}, \quad \varepsilon_{t} \sim N(0, \mathrm{I}), \\
\log \left(\sigma_{t}\right)=\log \left(\sigma_{t-1}\right)+\eta_{t},
\end{gathered}
$$

18) China's (real) retail sales and Korea's final goods exports to China are also used in turn

19) Japan's (real) retail sales and Korea's final goods exports to Japan are also used in turn.

20) Considering that the portions of primary goods are very low in all three countries (less than $5 \%$ in 2013), we abstract primary goods in subsequent analysis.

21) The export price indices of Korea are applied to Korea's exports to China and Japan, and Korea's import price indices are used for China's and Japan's exports to Korea. 
where $\sigma_{t}$ denotes the diagonal elements of $\Sigma_{t}$. The time-varying parameter assumption is applied to $\mathrm{B}_{i, t-i}, \mathrm{~A}_{t}$, and $\Sigma_{t}$. Note that, by employing the time-varying assumption to $\Sigma_{t}$, we control the effect of the volatility of the real exchange rate, which tends to increase sharply in the crisis period.

For the VAR lag length $p$, we choose $p=4$ for the 5 -variable analysis, and $p=6$ for the 4 -variable analysis. BIC and HQ suggest four or five lags. We in addition consider the number of parameters and observations, and the usual custom for monthly data, i.e. $p=6$.

By utilizing observations from 1998M1 to 2003M12 as a training sample for estimating prior information, we employ the Bayesian estimation method. As in Canova and Forero (2012), we apply Geweke and Tanizaki's (2001) multi-move Gibbs sampling within the Metropolis-Hastings algorithm. We discard the initial 5,000 draws, and save 200 draws in every 50th draw.

\subsection{Identification}

In the usual VAR estimation an identification problem is inevitable. In our model we assume that the real exchange rate affects the trade volume, but that this effect does not run in the opposite direction. The trade volume may affect the real exchange rate in practice, but employing monthly trade volume data would mitigate the endogeneity problem compared to the cases with quarterly or annual data.

In our 5-variable VAR, we impose identifying restrictions to allow interactions between Korea's intermediate goods exports to China (or Japan) and China's (or Japan's) intermediate goods exports to Korea. We construct the matrix $\mathrm{A}_{t}$ in equation (19) as shown in Table 1 . Table 1 applies to the other 5 -variable analyses in the same way.

In our 4-variable VAR, we adopt a recursive structure among the four variables to reflect the supply chains between the two countries concerned. The variables are in the order of the real exchange rate, China's exports to the US and the Euro area, Korea's final goods exports to China, and Korea's intermediate goods exports to China. We form the matrix $\mathrm{A}_{t}$ in equation (19) as shown in Table 2. Table 2 applies to the other 4 -variable analyses in the same way. 
Table 1: Identifying Restrictions for the 5-Variable Analysis

\begin{tabular}{l|c|c|c|c|c} 
CP 91 days & CP 91 days & RER & $\begin{array}{c}\text { CN EX to } \\
\text { US and EU }\end{array}$ & $\begin{array}{c}\text { KR EX to } \\
\text { CN (INT) }\end{array}$ & $\begin{array}{c}\text { CN EX to } \\
\text { KR (INT) }\end{array}$ \\
\hline RER & $\times$ & $\times$ & 0 & 0 & 0 \\
\hline CN EX to US and EU & $\circ$ & $\times$ & $\times$ & 0 & 0 \\
\hline KR EX to CN (INT) & 0 & $\times$ & $\times$ & $\times$ & $\times$ \\
\hline CN EX to KR (INT) & $\circ$ & $\times$ & $\times$ & $\times$ & $\times$ \\
\hline
\end{tabular}

Notes: 1) $X$ denotes no restriction, and 0 indicates zero restriction.

2) CN EX to US and EU represents China's exports to the US and the Euro area.

3) KR EX to CN (INT) denotes Korea's intermediate goods exports to China.

4) CN EX to KR (INT) indicates China's intermediate goods exports to Korea.

\subsection{Multistage production}

Using TVP VAR, we first explore how an increase in final demand in one country affects the intermediate goods exports of both that country and its trade partner. Theory suggests co-movements of the intermediate goods exports of both countries in the case where there is a multistage production process. In the previous theoretical analysis, we only considered final consumption goods, but for the empirical analysis we now extend our focus to include export goods in addition to final consumption goods, and investigate the Korea-China and the Korea-Japan country pairs in turn. We find a pattern of multistage production process deepening related to China's final goods consumption.

In Figure 3 we present the impact responses of Korea's intermediate goods exports to China and of China's intermediate goods exports to Korea with respect to three shocks - to China's exports to the US and the Euro area, to China's consumption expenditure, and to Korea's final goods exports to China.22) Depending upon the components of final demand, the effects of an increase in

22) The median responses of these three variables during six periods are given in the Appendices. The responses of the remaining two variables, i.e. 91-days $\mathrm{CP}$ and the real exchange rate, are omitted to avoid complexity. 
Table 2: Identifying Restrictions for the 4-Variable Analysis

\begin{tabular}{l|c|c|c|c} 
& RER & $\begin{array}{c}\text { CN EX to } \\
\text { US and EU }\end{array}$ & $\begin{array}{c}\text { KR EX to CN } \\
\text { (FIN) }\end{array}$ & $\begin{array}{c}\text { KR EX to CN } \\
\text { (INT) }\end{array}$ \\
\hline RER & $\times$ & 0 & 0 & 0 \\
\hline CN EX to US and EU & $\times$ & $\times$ & 0 & 0 \\
\hline KR EX to CN (FIN) & $\times$ & $\times$ & $\times$ & 0 \\
\hline KR EX to CN (INT) & $\times$ & $\times$ & $\times$ & $\times$ \\
\hline
\end{tabular}

Notes: 1) $X$ denotes no restriction, and 0 indicates zero restriction.

2) CN EX to US and EU represents China's exports to the US and the Euro area.

3) KR EX to CN (FIN) denotes Korea's final goods exports to China.

4) KR EX to CN (INT) indicates Korea's intermediate goods exports to China.

final demand on intermediate goods exports differs. As seen in the first row (a), an increase in China's exports to the US and the Euro area causes an increase in Korea's intermediate goods exports to China, but not in China's intermediate goods exports to Korea. This implies that, in China's production of export goods destined for the US and the Euro area, a multistage production process is not well established. China's export goods are accompanied by Korea's intermediate goods exports to China only. In the second row (b), a different pattern across intermediate goods exports appears. An increase in Chinese consumption expenditure causes increases in Korean intermediate goods exports to China and Chinese intermediate goods exports to Korea. This tendency becomes stronger as time passes. One can thus infer that the application of a multistage production process for producing China's consumption goods becomes stronger. The third row (c) reveals a similar although slightly different pattern compared to (b). In response to an increase in Korea's final goods exports to China, both Korea's and China's intermediate goods exports increase, but the strength of their co-movements weakens. 
Figure 3: Impact Responses to Various Shocks to Final Demand Components of Korea and China

(a) A Shock to China's exports to the US and the Euro area
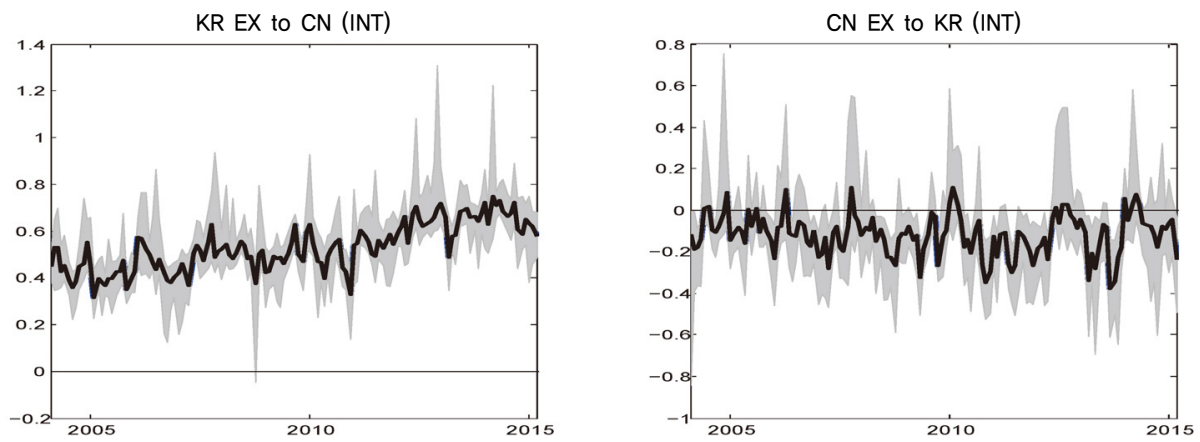

(b) A Shock to China's consumption expenditure
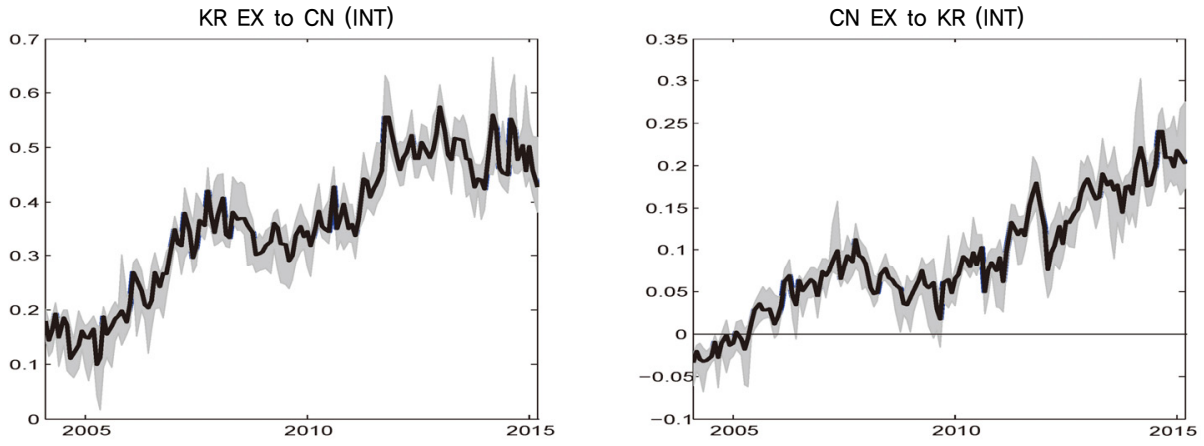

(c) A Shock to Korea's final goods exports to China
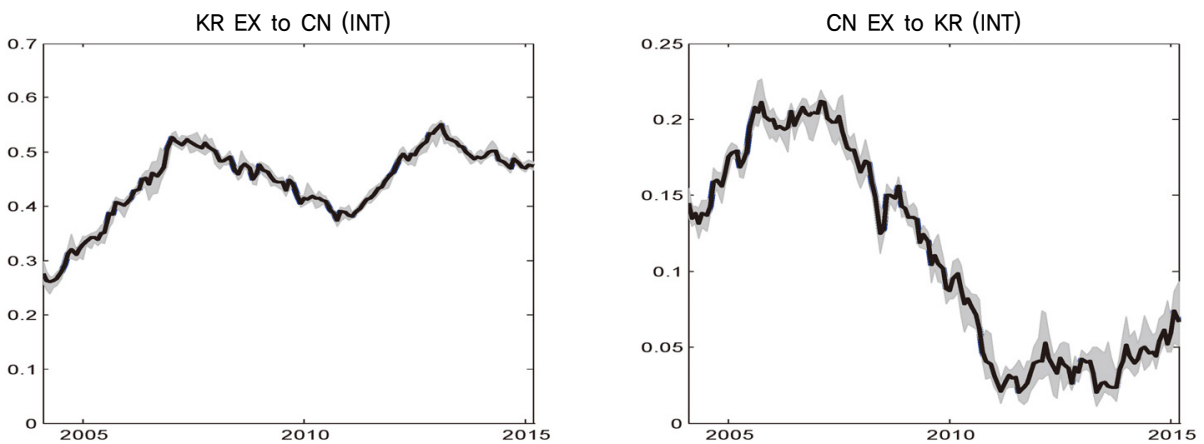

Notes: "KR EX to CN (INT)" and "CN EX to KR (INT)" represent "Korea's Intermediate Goods Exports to China" and "China's Intermediate Goods Exports to Korea" respectively. Horizontal line denotes (monthly) period. Shaded area represents $16 \sim 84 \%$ bands from Markov Chain Monte Carlo (MCMC) simulation. 
In Figure 4 we represent the impact responses of Korea's intermediate goods exports to Japan and of Japan's intermediate goods exports to Korea, with respect to shocks to Japan's exports to the US and the Euro area, Japan's consumption expenditure, and Korea's final goods exports to Japan.23) The first row (a) shows that an increase in Japan's exports to the US and the Euro area boosts Korea's intermediate goods exports to Japan, but not Japan's intermediate goods exports to Korea. As is apparent from Figure 3 (a), there is no clearly seen multistage production process between Korea and Japan. The second row (b) in Figure 4 shows that, in the production of Japan's consumption goods, no prominent multistage production process like China's exists. The third row (c) reveals that, in Korea's production of final goods exports to Japan, a multistage production process did seem to exist before 2010, but in recent years the positive effect on Japan's intermediate goods exports has disappeared.

\subsection{Ef fects of real exchange rate movements}

Considering the changing patterns of trade in East Asia, it is important to investigate how the trade structures among countries influences the effects of real exchange rate movements. Compared to investigating a multistage production process, analyzing the effects of real exchange rate fluctuations on the trade volume is more complicated. When we consider only final consumption goods the analysis is straight forward. However, we need to consider final export goods together, and this makes the transmission mechanism of real exchange rate movements complicated. Note that the real exchange rate fluctuations have an effect on final and intermediate goods exports, and that the change in final goods exports affects intermediate goods exports in addition.

In Figure 5 we depict possible channels through which the real exchange rate affects trade volumes. Fluctuations in the real exchange rate have a direct impact on the competitiveness of China's (or Japan's) exports to the US and the Euro

23) The median responses of these three variables during six periods are given in the Appendices. The responses of the remaining two variables, i.e. 91 days $\mathrm{CP}$ and the real exchange rate, are omitted to avoid complexity. 
Figure 4: Impact Responses to Various Shocks to Final Demand Components of Korea and Japan

(a) A Shock to Japan's exports to the US and the Euro area
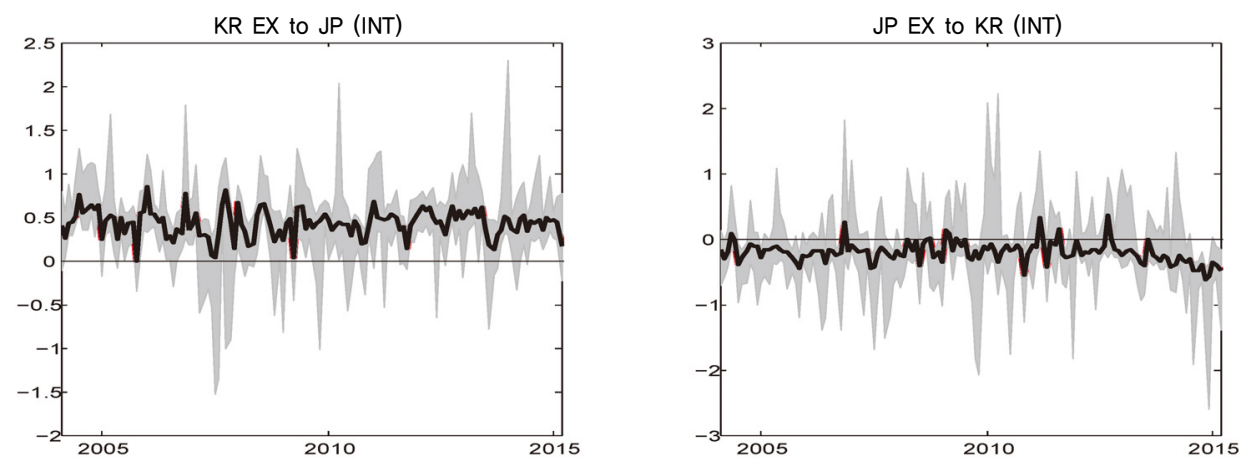

(b) A Shock to Japan's consumption expenditure
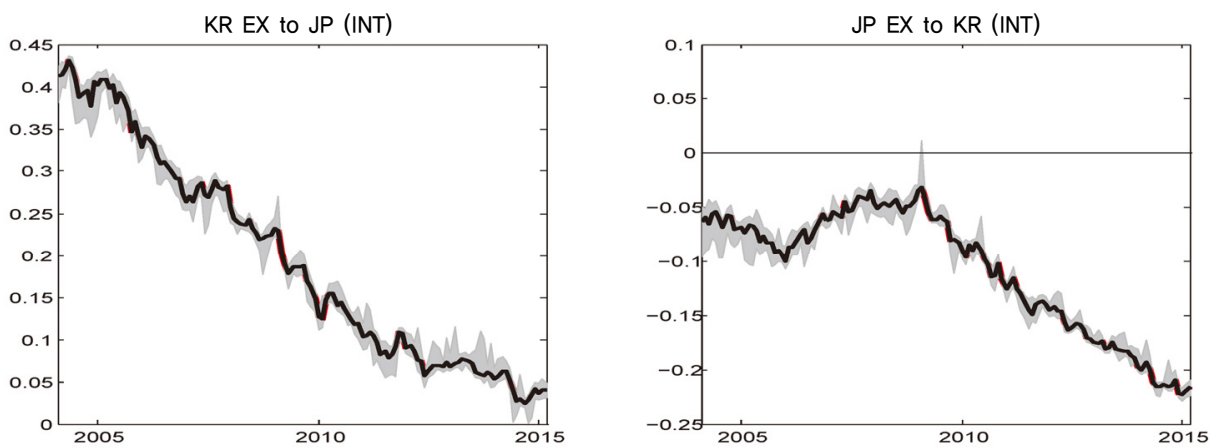

(c) A Shock to Korea's final goods exports to Japan
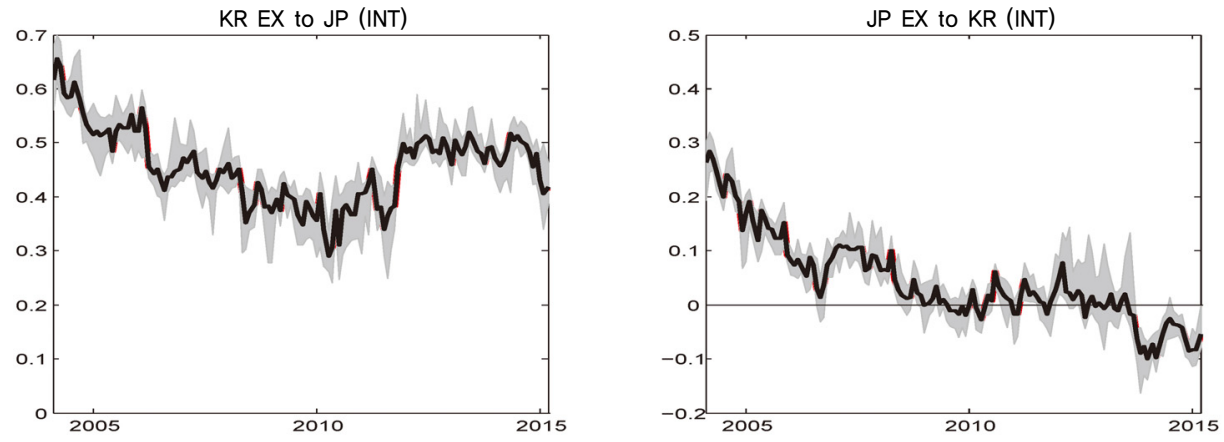

Notes: "KR EX to JP (INT)" and "JP EX to KR (INT)" represent "Korea's Intermediate Goods Exports to Japan" and "Japan's Intermediate Goods Exports to Korea" respectively. Horizontal line denotes (monthly) period. Shaded area represents $16 \sim 84 \%$ bands from Markov Chain Monte Carlo (MCMC) simulation. 
Figure 5: Transmission Mechanism of Fluctuations in the Real Terms of Trade

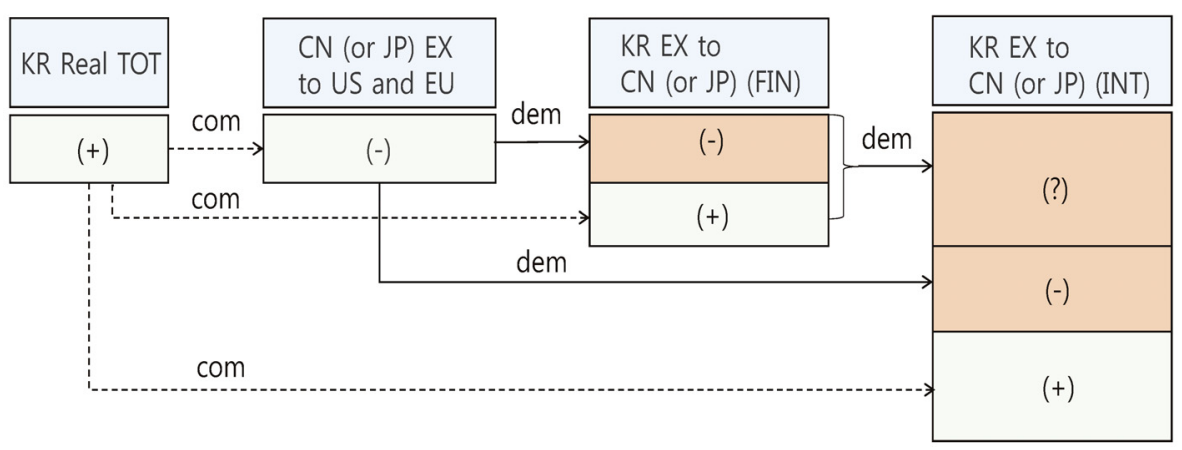

- dem: demand effect

- com: competitiveness effect

area, Korea's final goods exports to China (or Japan), and Korea's intermediate goods exports to China (or Japan). These effects may vary depending on the existence of a multistage production process as previously discussed. In addition to competitiveness channels, changes in China's (or Japan's) exports and in Korea's final goods exports have demand effects on Korea's intermediate goods exports. 24$)$

We explore the efects of the real exchange rate movements on trade volume, focusing on whether these effects have changed over time. From the results of TVP VAR estimation, we construct annual impulse responses for the years 2005, 2008, 2011 and 2014.

\subsubsection{Korea-China country pair}

Figure 6 shows how the effects of the real exchange rate fluctuations between Korea-China differ across the time periods. What is notable is that the movements of trade volumes in responses to real exchange rate shocks have not changed much, excepting the case of Korea's intermediate goods exports

24) Changes in China's (or Japan's) exports have demand effects on Korea's final goods exports as well. 
Figure 6: Responses to a Shock to the (Won-Yuan) Real Exchange Rate (Real Yuan Appreciation)
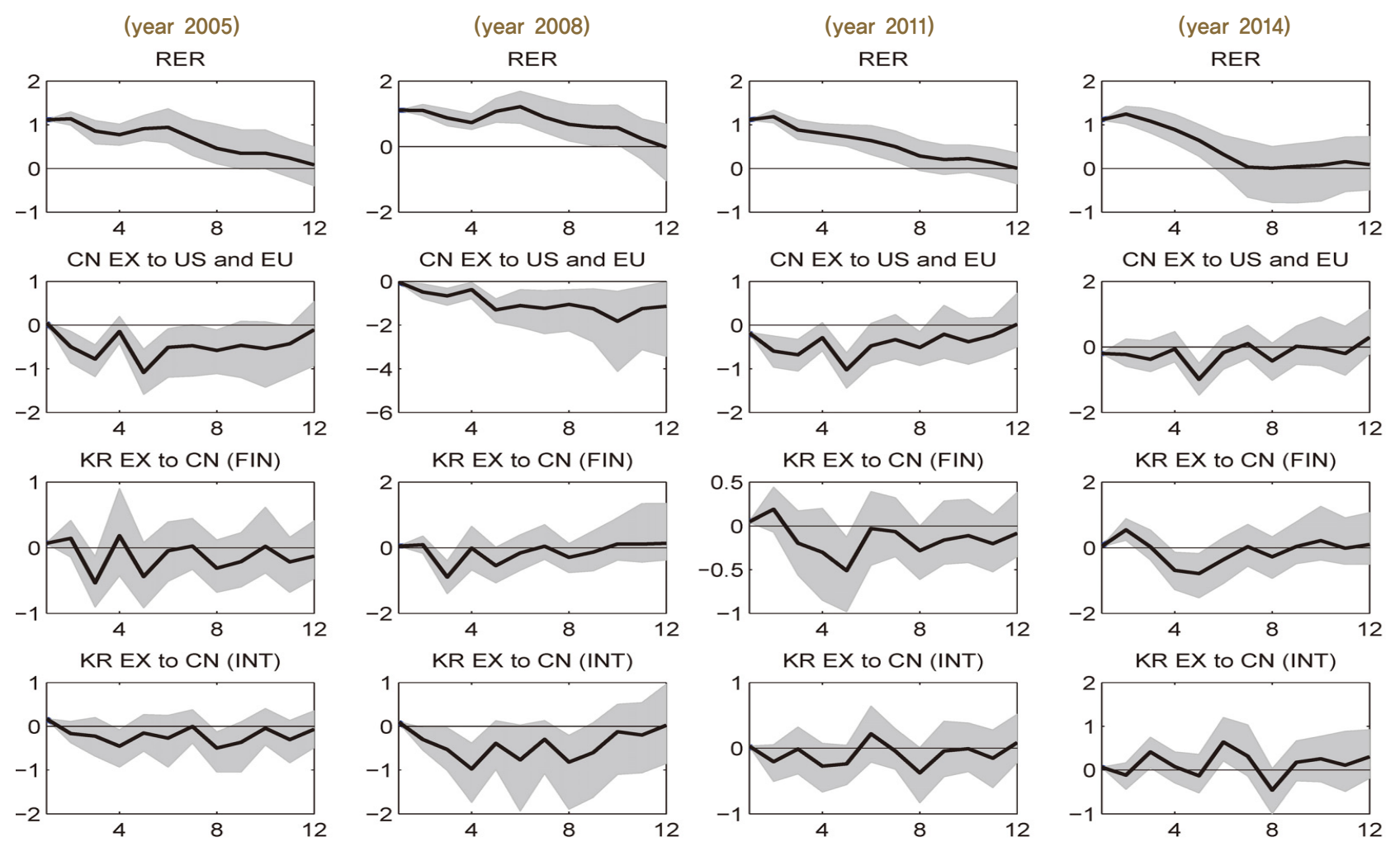

Notes: First column, second column, third column and fourth column are year 2005, year 2008, year 2011 and year 2014 responses respectively. "RER", "CN EX to US and EU", "KR EX to CN (FIN)" and "KR EX to CN (INT)" represent "the (Won-Yuan) Real Exchange Rate", "China's Exports to the US and the Euro area", "Korea's Final Goods Exports to China" and "Korea's Intermediate Goods Exports to China" respectively. Horizontal line denotes (monthly) period. Shaded area represents $16 \sim 84 \%$ bands of annual draws from Markov Chain Monte Carlo (MCMC) simulation. 


\section{$21 \quad$ BOK Working Paper No.2015-29 (2015.11)}

to China. An increase in the won-yuan real exchange rate (i.e. real yuan appreciation) has a negative effect on China's exports to the US and the Euro area. This implies potential positive effects on Korea's exports to the US and the Euro area, mainly in the industries in competition with China, although we do not directly include this variable in our estimation to avoid an insufficient degree of freedom. Real yuan appreciation against the won additionally causes Korea's final goods exports to China to increase for from one to three months. After this, Korea's final goods exports begin to decline. We conjecture that a dampening demand effect due to the decline in Chinese exports counteracts the positive competitiveness effect.

However, the responses of Korea's intermediate goods exports vary over time. Since 2011 the positive impact on Korea's intermediate goods exports has become more vivid. These diverse movements of Korea's intermediate goods exports can be explained by the trend of a deepening multistage production process. As can be seen in Figure 3, concerning Korea and China, the pattern of multistage production for China's consumption goods strengthens. Even though China's consumption good demand is not affected by the real exchange rate, the productivity gain (i.e. the increase in $\underline{z}$ in equation (17)) amplified by the input-output structures of China and Korea leads to an expansion in Korea's intermediate goods exports. One thing of note is that the presence of a multistage production process causes China's intermediate goods exports to increase as well.

\subsubsection{Korea-Japan country pair}

Figure 7 displays the effects of the real exchange rate fluctuations between Korea and Japan. The role of (real) price competitiveness played in the countries' bilateral trade has changed over time. In 2005 price competitiveness plays little role in explaining the trade volume movements. ${ }^{25)}$ In 2008 an increase in the (won-yen) real exchange rate (i.e. real yen appreciation) leads to a reduction in

25) Given that our VAR is constructed with four variables, there may be some missing explanatory variables that are important for explaining the trade volume movements. 
Figure 7: Responses to a Shock to the (Won-Yen) Real Exchange Rate (Real Yen Appreciation)
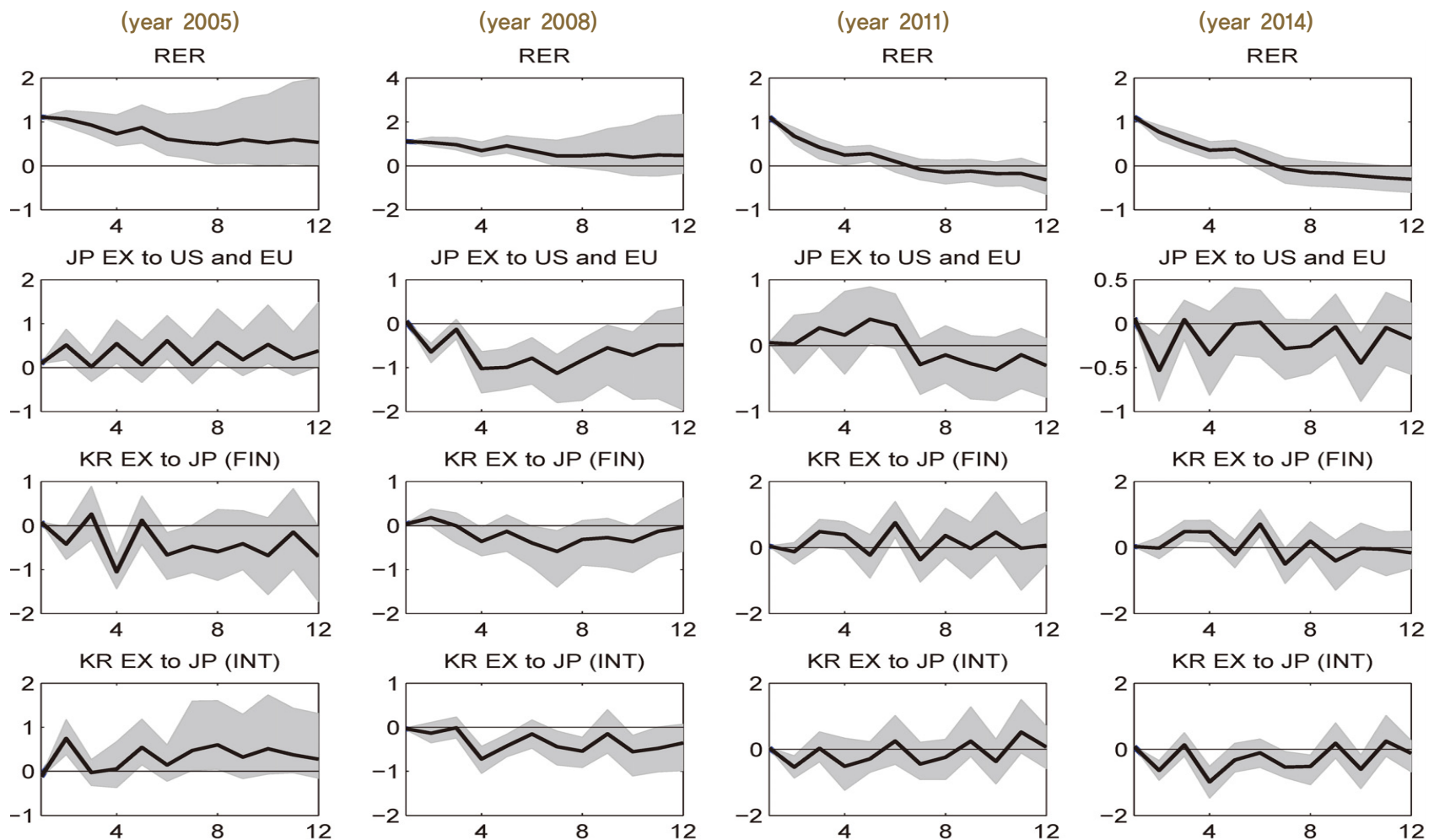

Notes: First column, second column, third column and fourth column are year 2005, year 2008, year 2011 and year 2014 responses respectively. "RER", "JP EX to US and EU", "KR EX to JP (FIN)" and "KR EX to JP (INT)" represent "the (Won-Yen) Real Exchange Rate", "Japan's Exports to the US and the Euro Area", "Korea's Final Goods Exports to Japan" and "Korea's Intermediate Goods Exports to Japan" respectively. Horizontal line denotes (monthly) period. Shaded area represents $16 \sim 84 \%$ bands of annual draws from Markov Chain Monte Carlo (MCMC) simulation. 
Japan's exports to the US and the Euro area. Real appreciation does not have a positive effect on Korea's final goods exports to Japan. In 2014 real yen appreciation against the won generates a decline in Japanese exports to US the and the Euro area, implying an increase in Korea's final goods exports to those areas. This indicates that, in the export markets outside this region the importance of price competitiveness has remained.

In each year, Korea's intermediate goods exports to Japan seems to depend upon Japan's exports to the US and the Euro area. Recently, Korea's intermediate goods exports to Japan have decreased upon the real yen appreciation taking place (see Figure 15 in Appendices). As revealed in Figure 4, the multistage production process between the Korea-Japan country pair is very weak. Hence the amplified effect of real depreciation is not large enough to counteract the negative demand effect.

Compared to the Korea-China country pair, the Korea-Japan country pair represents different movements in terms of Korea's total exports. We consider the year 2014 for example. Even though we do not explicitly include Korea's exports to the US and the Euro area, we can conjecture that an increase in the (won-yen) real exchange rate leads to an expansion in Korea's exports to those destination, which is similar to the case with Korea-China trade. In addition, Korea's final goods exports to Japan increase in response to real yen appreciation. One distinct feature, however, is that Korea's intermediate goods exports to Japan display a decrease. Overall, whether Korea's total exports to Japan increase or decrease is unclear. What is clear is that there is a switching in the components of exports, i.e. an increase in final goods exports and a decrease in intermediate goods exports.

\section{Concluding Remarks}

Observing the trend of increasing global vertical trade, we analyze the vertical specialization patterns involving the Korea-China and the Korea-Japan country pairs, as well as the effects of real exchange rate fluctuations. To this end we develop a simple two-country model and adopt the Time-Varying Parameter (TVP) VAR method for estimation. 
Based on a Ricardian two-country model, we derive two features of global vertical specialization where multistage production processes across countries occur. One prominent prediction is that, when a multistage production process exists, an expansion in final demand in one country causes both countries' intermediate goods exports to increase at the same time. Intuitively, if two countries' production processes are closely linked, then a final demand increase will raise both of their intermediate goods exports through a circulating chain. The second feature is that, if a multistage production process exists in the production of one country's final goods, then real depreciation in the other country displays an effect of amplifying the trade volumes through a circulating chain of the input-output structure.

In our attempts to empirically verify these features, through TVP VAR method, we first investigate which components of final demand are related to the multistage production process. What we find is that the multistage production process between China and Korea is different from that between Japan and Korea. In trade between China and Korea, a multistage process in the production of Chinese consumption goods is well established. The degree of this multistage production process seems to strengthen as time passes. However, in the case of the trade between Japan and Korea, no significant multistage production process exists.

Another finding is that, because of the different patterns of the multistage production processes between the country pairs, the effects of real exchange rate fluctuations on Korea's intermediate goods exports also differs between the two country pairs across time. In the China-Korea pair, real depreciation has a significant positive effect on Korea's intermediate goods exports, reflecting the recent stronger degree of multistage production. This is because the amplified effect of real depreciation counteracts the negative effect of falling Chinese demand on Korea's intermediate goods exports. In the Japan-Korea pair, we find intermediate goods trade to be weakening. This finding may reflect the increasing role of China in multistage production associated with intermediate goods trade in the East Asia region. 


\section{References}

Arize, A. C. (1995), “The Effects of Exchange-Rate Volatility on U. S. Exports: An Empirical Investigation," Southern Economic Journal, Vol. 62(1), pp. 34-43.

Arize, A. C., T. Osang, and D. J. Slottje (2000), "Exchange-Rate Volatility and Foreign Trade: Evidence From Thirteen LDC's," Journal of Business \& Economic Statistics, Vol. 18(1), pp. 10-17.

Athukorala, P.-c. (2005), "Product Fragmentation and Trade Patterns in East Asia," Asian Economic Papers, Vol. 4, pp. 1-27.

Athukorala, P.-c. and N. Yamashita (2006), "Production Fragmentation and Trade Integration: East Asia in a Global Context," The North American Journal of Economics and Finance, Vol. 17, pp. 233-256.

Baak, S. J., M. A. Al-Mahmood, and S. Vixathep (2007), "Exchange Rate Volatility and Exports from East Asian Countries to Japan and the USA," Applied Economics, Vol. 39(8), pp. 947-959.

Berthou, A. (2008), "An Investigation on the Effect of Real Exchange Rate Movements on OECD Bilateral Exports," European Central Bank Working Paper No. 0920.

Canova, F., and F. J. P. Forero (2012), "Estimating Overidentified, Nonrecursive, Time-Varying Coefficients Structural VARs," Economics Working Papers No. 1321, Department of Economics and Business, Universitat Pompeu Fabra.

Chou, W. L. (2000), "Exchange Rate Variability and China's Exports," Journal of Comparative Economics, Vol. 28(1), pp. 61-79.

Chowdhury, A. R. (1993), "Does Exchange Rate Volatility Depress Trade Flows? Evidence from Error-Correction Models," The Review of Economics and Statistics, Vol. 75(4), pp. 700-706.

Dornbusch, R., S. Fischer, and P. A. Samuelson (1977), "Comparative Advantage, Trade, and Payments in a Ricardian Model with a Continuum of Goods," American Economic Review, Vol. 67(5), pp. 823-839. 
Geweke, J., and H. Tanizaki (2001), "Bayesian Estimation of State-Space Models Using the Metropolis-Hastings Algorithm within Gibbs Sampling," Computational Statistics \& Data Analysis, Vol. 37, pp. 151-170.

Greenaway, D., R. Kneller, and X. Zhang (2010), "The Effect of Exchange Rates on Firm Exports: The Role of Imported Intermediate Inputs," The World Economy, Vol. 33(8), pp. 961-986.

Hummels, D., J. Ishii, and K.-M. Yi (2001), "The Nature and Growth of Vertical Specialization in World Trade," Journal of International Economics, Vol. 54(1), pp. 75-96.

Kim, S., N. Shephard, and S. Chib (1998), "Stochastic Volatility: Likelihood Inference and Comparison with ARCH Models," Review of Economic Studies, Vol. 65(3), pp. 361-393.

Kimura, F., Y. Takahashi, and K. Hayakawa (2007), "Fragmentation and Parts and Components Trade: Comparison between East Asia and Europe," The North American Journal of Economics and Finance, Vol. 18, pp. 23-40.

Primiceri, G. E. (2005), "Time Varying Structural Vector Autoregressions and Monetary Policy," The Review of Economic Studies, Vol. 72(3), pp. 821-852.

Rose, A. K. (2000), "One Money, One Market: the Effect of Common Currencies on Trade," Economic Policy, Vol. 15(30), pp. 7-46.

Suh, Y. K. (2008), "The Growth and Determinants of Vertical Trade in Korea," BOK Working Paper No. 327, Institute for Monetary and Economic Research.

Thorbecke, W. (2008), "The Effect of Exchange Rate Volatility on Fragmentation in East Asia: Evidence from the Electronics Industry," Journal of the Japanese and International Economies, Vol. 22(4), pp. 535-544.

Wakasugi, R. (2007), "Vertical Intra-Industry Trade and Economic Integration in East Asia," Asian Economic Papers, Vol. 6, pp. 26-39.

Yi, K.-M. (2003), "Can Vertical Specialization Explain the Growth of World Trade?" Journal of Political Economy, Vol. 111(1), pp. 52-102.

Yi, K.-M. (2010): "Can Multistage Production Explain the Home Bias in Trade?" American Economic Review, Vol. 100(1), pp. 364-393. 


\section{Appendices}

\section{A. Derivation of breakpoints}

\section{A.1. Derivation of breakpoint in one-stage model}

Goods finally consumed in the foreign country can be produced either in the foreign or in the home country. The arbitrage condition that the prices of those goods are the same, implies

$$
p^{F}(\underline{z})=\frac{\left(W^{F}\right)^{1-\theta_{1}}\left(P^{F}\right)^{\theta_{1}}}{A^{F}(\underline{z})}=\operatorname{tot}^{H F} \frac{\left(W^{H}\right)^{\left(1-\theta_{1}\right)}\left(P^{H}\right)^{\theta_{1}}}{A^{H}(\underline{z})} \equiv \operatorname{tot}^{H F} p^{H}(\underline{z}),
$$

where $t o t^{H F}$ denotes the unit price of home currency in terms of foreign currency. Rearranging gives

$$
\left(\frac{W^{F}}{W^{H}}\right)^{1-\theta_{1}}\left(\frac{P^{F}}{P^{H}}\right)^{\theta_{1}}=\left(\frac{A^{H}(\underline{z})}{A^{F}(\underline{z})}\right) \operatorname{tot}^{H F} .
$$

By assuming symmetry and applying a Frechét distribution, we further simplify the above relation to

$$
1=\left(\frac{1-\underline{z}}{\underline{z}}\right)^{\frac{1}{n}} t^{H F}
$$

\section{A.2. Derivation of breakpoint in multistage model}

For goods finally consumed in the foreign country, two production methods exist as in the Case 1. Stage 1 goods are produced in the foreign country, but stage 2 goods can be produced either in the foreign or in the home country, i.e. FF or FH. The arbitrage condition that the prices of stage 2 goods are the same across FF and FH, implies 


$$
\begin{aligned}
p_{2}^{F F}(\underline{z}) & \equiv \frac{B\left(W^{F}\right)^{1-\theta_{1} \theta_{2}}\left(P^{H}\right)^{\theta_{1} \theta_{2}}}{A_{1}^{F}(\underline{z})^{\theta_{2}} A_{2}^{F}(\underline{z})^{1-\theta_{2}}} \\
& =\operatorname{tot}^{H F} \frac{B\left(t o t^{F H}\right)^{\theta_{2}}\left(W^{F}\right)^{\left(1-\theta_{1}\right) \theta_{2}}\left(P^{H}\right)^{\theta_{1} \theta_{2}}\left(W^{F}\right)^{1-\theta_{2}}}{A_{1}^{F}(\underline{z})^{\theta_{2}} A_{2}^{H}(\underline{z})^{1-\theta_{2}}} \\
& \equiv \operatorname{tot}^{H F} p^{F H}(\underline{z}),
\end{aligned}
$$

where $B$ denotes a constant. Rearranging gives

$$
\left(\frac{W^{F}}{W^{H}}\right)^{1-\theta_{2}}=\left(\frac{A_{2}^{H}(\underline{z})}{A_{2}^{F}(\underline{z})}\right)^{1-\theta_{2}}\left(\operatorname{tot}^{H F}\right)^{1-\theta_{2}} .
$$

By assuming symmetry and applying a Frechét distribution, we further simplify the above relation to

$$
1=\left(\frac{1-\underline{z}}{\underline{z}}\right)^{\frac{1-\theta_{2}}{n}}\left(\operatorname{tot}^{H F}\right)^{1-\theta_{2}}
$$

One can solve for $\underline{z}$ as in (17). 


\section{B. Median responses to shocks to final demand}

\section{B.1. Median responses in the Korea-China country pair}

Figure 8: Median Responses to a Shock to

China's Exports to the US and the Euro Area

Response of CN EX to US and EU

Response of KR EX to CN (INT)

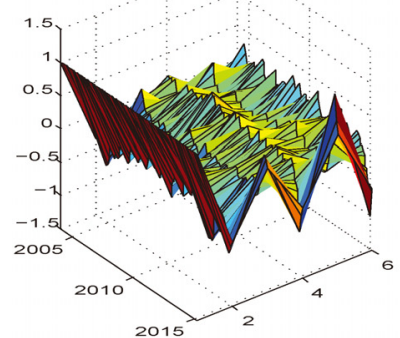

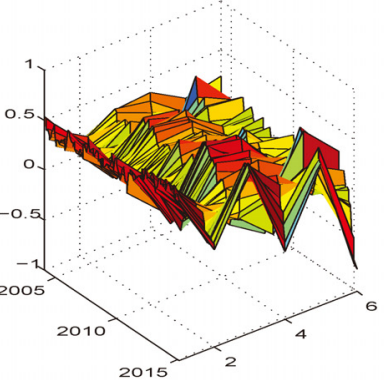

Response of CN EX to KR (INT)

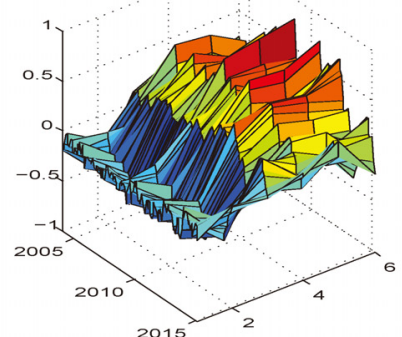

Notes: "CN EX to US and EU", "KR EX to CN (INT)" and "CN EX to KR (INT)" represent "China's Exports to the US and the Euro Area", "Korea's Intermediate Goods Exports to China" and "China's Intermediate Goods Exports to Korea" respectively. Horizontal $x-y$ space denotes (monthly) period and (monthly) time span.

Figure 9: Median Responses to a Shock to China's Consumption Expenditure

Response of CN CONS

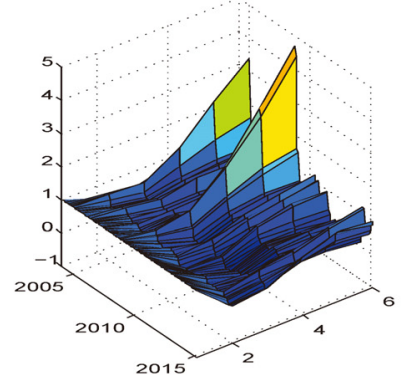

Response of KR EX to CN (INT)

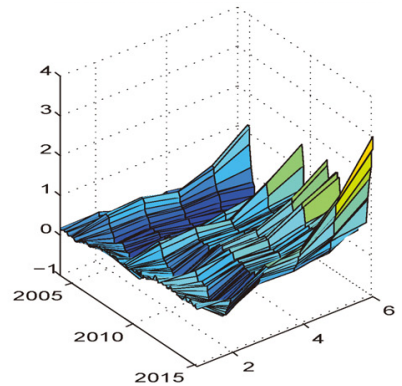

Response of CN EX to KR (INT)

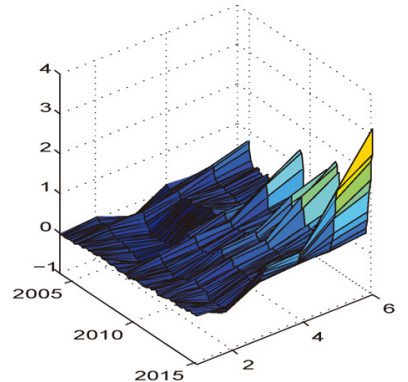

Notes: "CN CONS", "KR EX to CN (INT)" and "CN EX to KR (INT)" represent "China's Consumption Expenditure", "Korea's Intermediate Goods Exports to China" and "China's Intermediate Goods Exports to Korea" respectively. Horizontal $x$-y space denotes (monthly) period and (monthly) time span. 


\section{Figure 10: Median Responses to a Shock to Korea's Final Goods Exports to China}

Response of KR EX to CN (FIN)

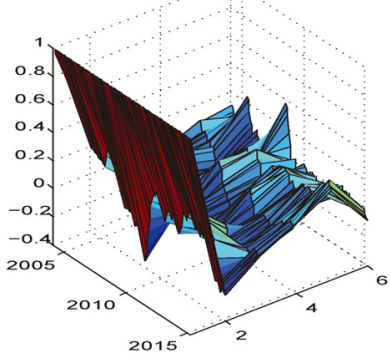

Response of KR EX to CN (INT)

Response of CN EX to KR (INT)

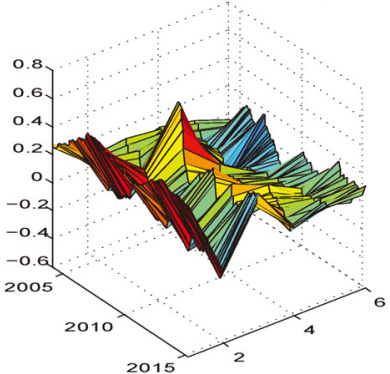

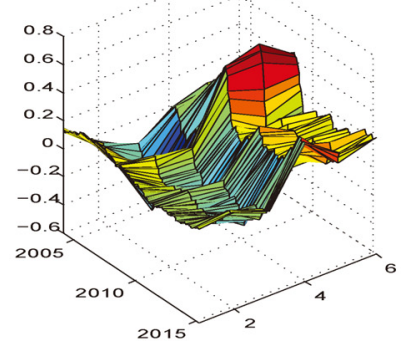

Notes: "KR EX to CN (FIN)", "KR EX to CN (INT)" and "CN EX to KR (INT)" represent "Korea's Final Goods Exports to China", "Korea's Intermediate Goods Exports to China" and "China's Intermediate Goods Exports to Korea" respectively. Horizontal $x-y$ space denotes (monthly) period and (monthly) time span.

\section{B.2. Median responses in the Korea-Japan country pair}

\section{Figure 11: Median Responses to a Shock to Japan's Exports to the US and the Euro Area}

Response of JP EX to US and EU

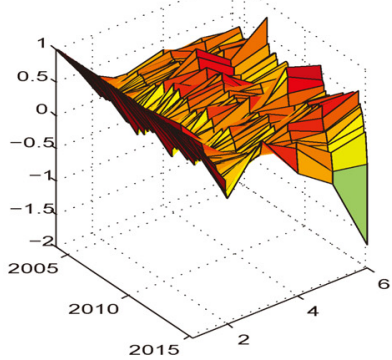

Response of KR EX to JP (INT)

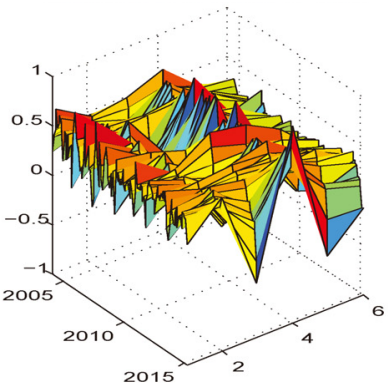

Response of JP EX to KR (INT)

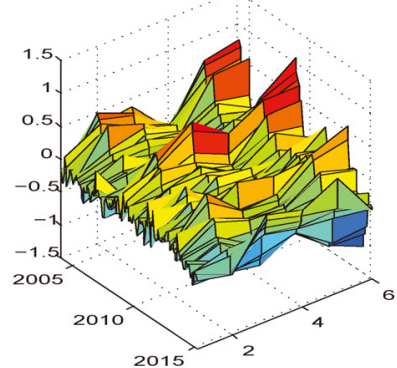

Notes: "JP EX to US and EU", "KR EX to JP (INT)" and "JP EX to KR (INT)" represent "Japan's Exports to the US and the Euro Area", "Korea's Intermediate Goods Exports to Japan" and "Japan's Intermediate Goods Exports to Korea" respectively. Horizontal x-y space denotes (monthly) period and (monthly) time span. 


\section{Figure 12: Median Responses to a Shock to Japan's Consumption Expenditure}

Response of JP CONS

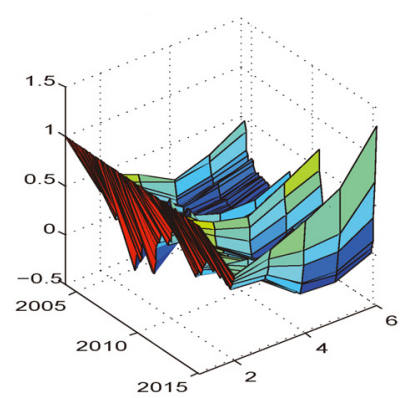

Response of KR EX to JP (INT)

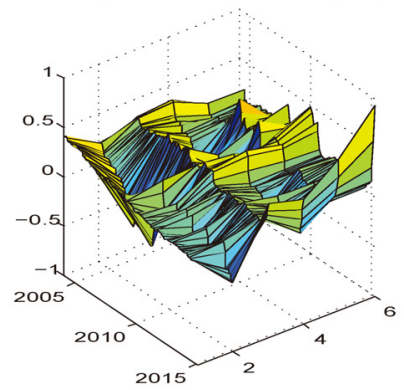

Response of JP EX to KR (INT)

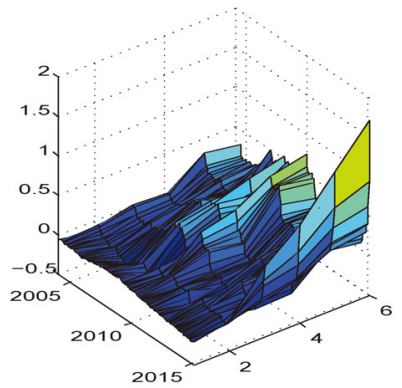

Notes: "JP CONS", "KR EX to JP (INT)" and "JP EX to KR (INT)" represent "Japan's Consumption Expenditure", "Korea's Intermediate Goods Exports to Japan" and "Japan's Intermediate Goods Exports to Korea" respectively. Horizontal x-y space denotes (monthly) period and (monthly) time span.

\section{Figure 13: Median Responses to a Shock to} Korea's Final Goods Exports to Japan

Response of KR EX to JP (FIN)

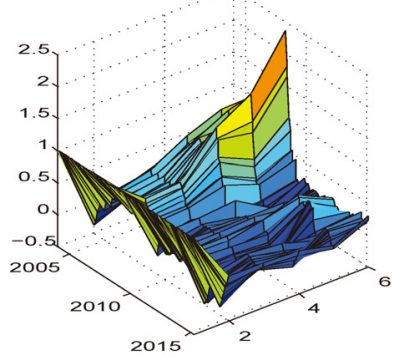

Response of KR EX to JP (INT)

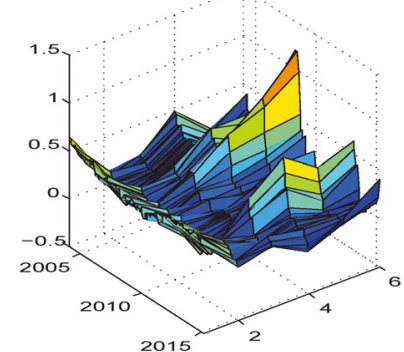

Response of JP EX to KR (INT)

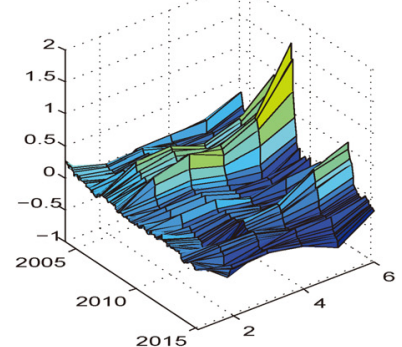

Notes: "KR EX to JP (FIN)", "KR EX to JP (INT)" and "JP EX to KR (INT)" represent "Korea's Final Goods Exports to Japan", "Korea's Intermediate Goods Exports to Japan" and "Japan's Intermediate Goods Exports to Korea" respectively. Horizontal x-y space denotes (monthly) period and (monthly) time span. 
C. Median responses to shocks to the real exchange rate

Figure 14: Median Responses to a Shock to the Real Exchange Rate
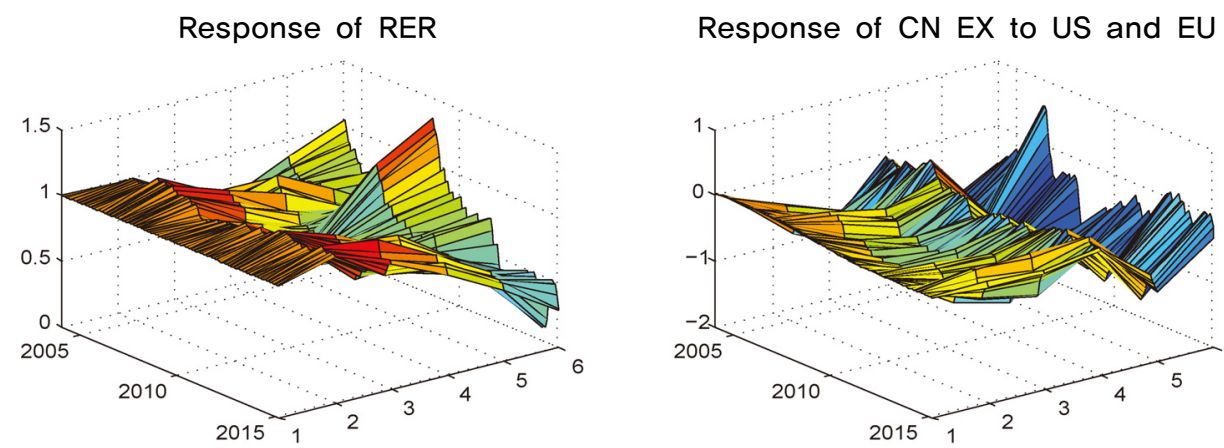

\section{Response of KR EX to CN (FIN)}
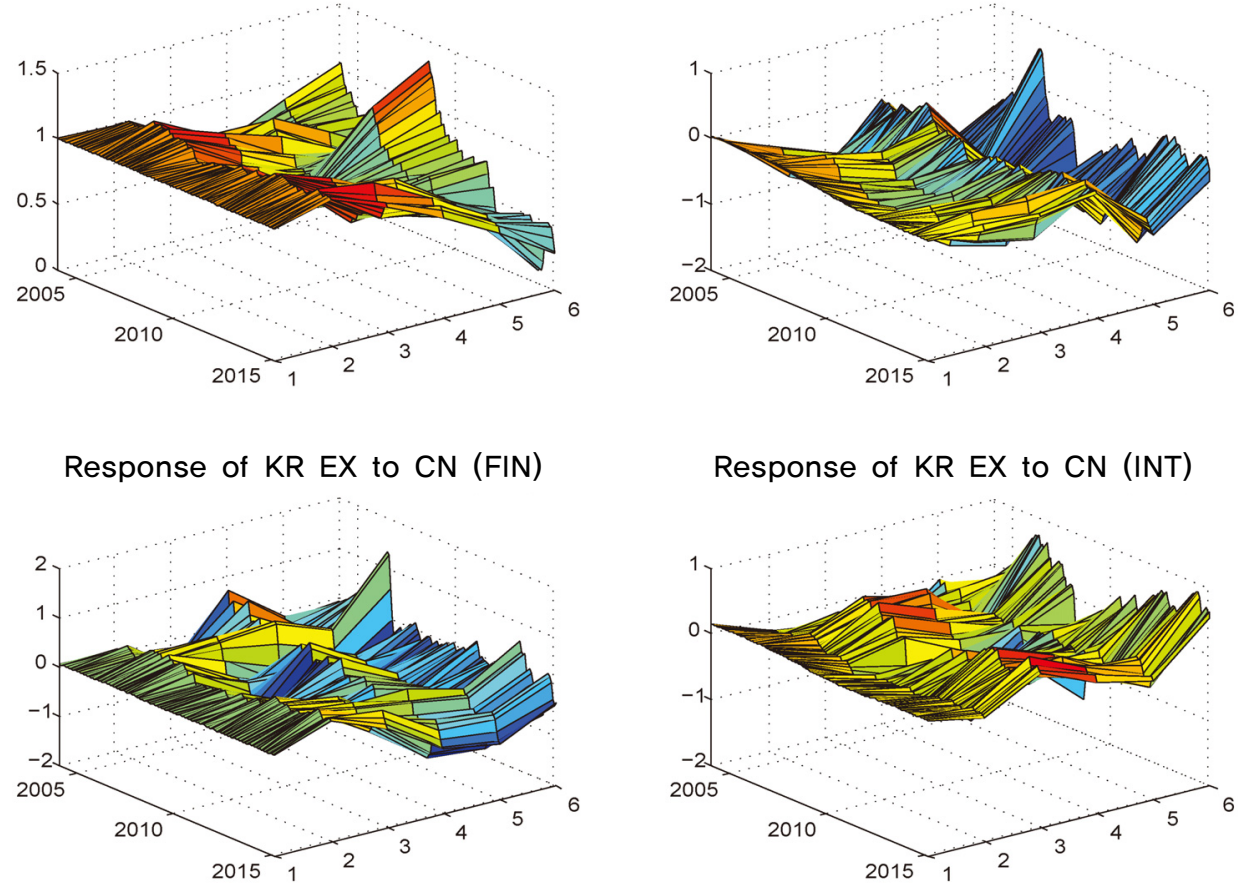

Response of KR EX to CN (INT)

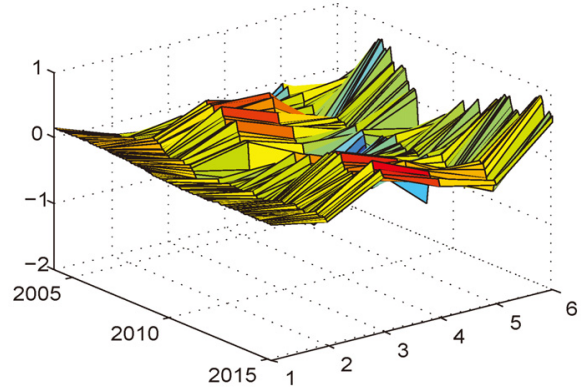

Notes: "RER", "CN EX to US and EU", "KR EX to CN (FIN)" and "KR EX to CN (INT)" represent "the (Won-Yuan) Real Exchange Rate", "China's Exports to the US and the Euro Area", "Korea's Final Goods Exports to China" and "Korea's Intermediate Goods Exports to China" respectively. Horizontal $x-y$ space denotes (monthly) period and (monthly) time span. 
Figure 15: Median Responses to a Shock to the Real Exchange Rate
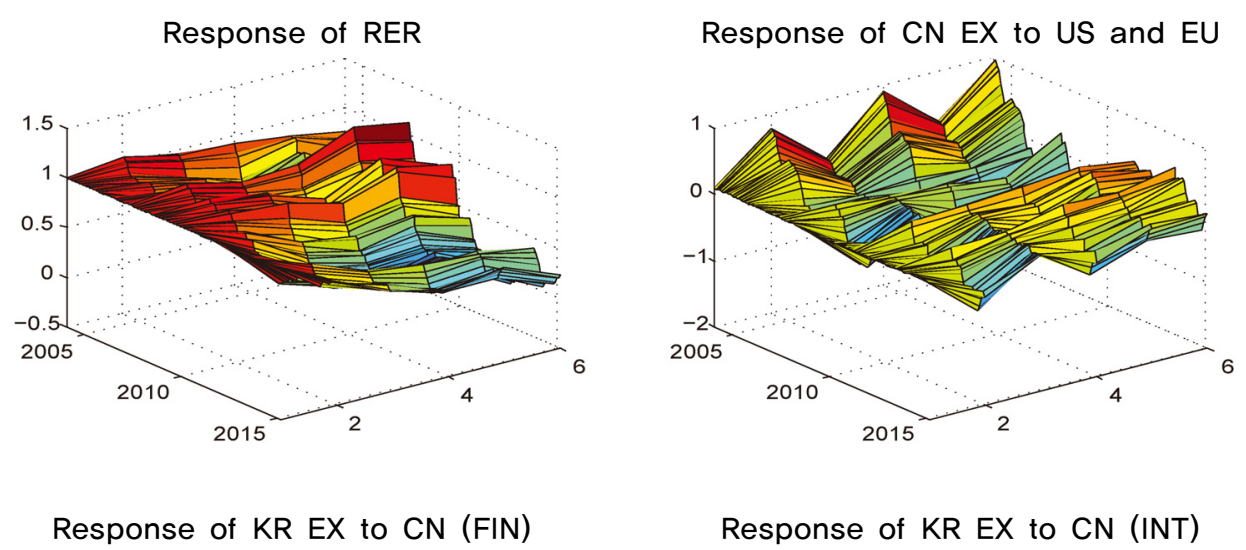

Response of KR EX to CN (INT)
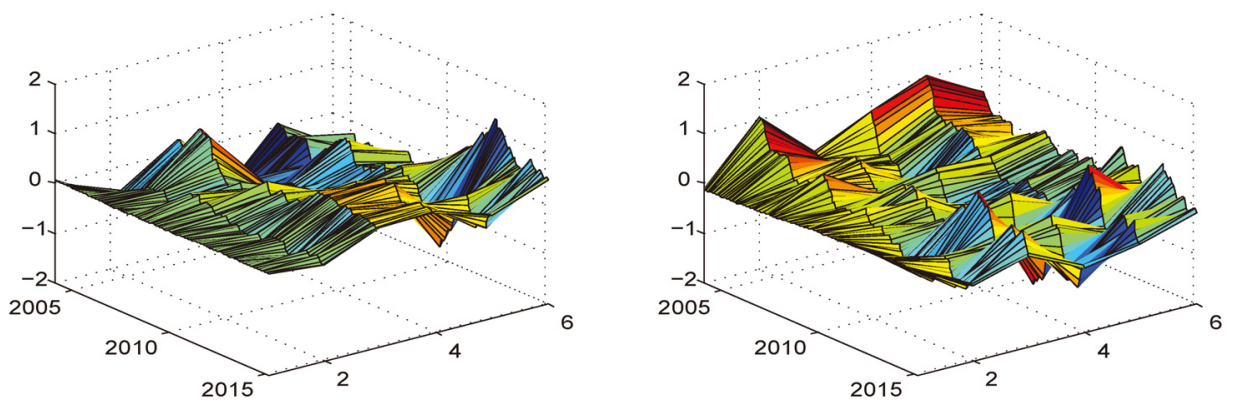

Notes: "RER", "JP EX to US and EU", "KR EX to JP (FIN)" and "KR EX to JP (INT)" represent "the (Won-Yen) Real Exchange Rate", "Japan's Exports to the US and the Euro Area", "Korea's Final Goods Exports to Japan" and "Korea's Intermediate Goods Exports to Japan" respectively. Horizontal $x-y$ space denotes (monthly) period and (monthly) time span. 


\section{$<$ Abstract in Korean $>$ \\ 한 · 중 · 일 간 역내 무역구조 변화와 \\ 실질환율의 영향력 분석}

최 문 정*, 김 근 영**, 이 주 용***

본 연구에서는 다단계 분업구조의 관점에서 한-중, 한-일 간 역내 무역구조 의 특징을 살펴보고, 역내 무역구조 변화에 따라 실질환율 변동이 역내 국 가 간 수출에 미치는 영향이 어떻게 달라졌는지를 이론적 및 실증적으로 분석 하였다. 먼저 2 국간 중간재 생산에서의 다단계 생산체인을 명시적으로 고 려한 이론모형 분석을 통해 다단계 생산과정이 형성된 수직적 무역구조 의 두 가지 특징을 제시하였다. 첫째, 한 국가의 최종수요 증대는 양 국가간 상호 중간재 수출 증대를 야기한다. 둘째, 상대국 통화의 실질가치 절하는 무역거래의 순환고리를 통해 상대국의 중간재 수출을 증폭시키는 효과를 가져 온다. 이러한 분석결과를 토대로 시변계수 VAR 기법을 한·중·일 간 무역자료에 적용하여 실증분석한 결과, 이론모형의 특징이 실제로 한-중, 한-일 간 교역에 상이한 양상으로 전개되고 있는 것으로 나타났다. 즉 i) 중국의 최종 소비재 생산과 연계된 다단계 생산과정이 강화되고 있는 반면 한-일간 무역에는 다단계 생산체인이 미약한 것으로 나타났으며, ii) 이러한 역내 무역구조의 변화로 인해 실질환율이 중간재 교역에 미치는 증폭효과가 한-중 간에 강화되고 있는 것으로 나타났다.

핵심주제어: 수직적 무역, 다단계 생산구조, 실질환율, 시변계수 VAR

JEL Classification: C32, F12, F12, F15

\footnotetext{
* 한국은행 경제연구원 국제경제연구실 전문연구원

** 한국은행 경제연구원 국제경제연구실장

*** 한국은행 경제연구원 국제경제연구실 전문연구원
}

이 연구내용은 집필자의 개인의견이며 한국은행의 공식견해와는 무관합니다. 따라서 본 논문의 내용을 보도하거나 인용할 경우에는 집필자명을 반드시 명시하여 주시기 바랍니다. 